DOI: 10.22363/2312-8313-2018-5-2-216-228

\title{
Patriotism as a value in the globalizing world: national and international 'measurements'
}

\author{
I.V. Trotsuk \\ Peoples' Friendship University of Russia (RUDN University) \\ 6 Miklukho-Maklaya St., Moscow, 117198, Russia
}

\begin{abstract}
The article considers patriotism as one of the most difficult social concepts to be 'measured' for it has different interpretations and 'dimensions' that are discursive rather than determined by objective factors. First, the author outlines the results of the Russian opinion polls in the 2010 s, 2000s and 1990s, which indicate changes in the interpretations of patriotism by the shares of the population willing to identify themselves as patriots. The figures stabilized in the mid2000 s, which was also determined by the state's efforts to use the idea of patriotism to support the legitimacy of state bodies and national solidarity under the intensifying globalization. Since 2001 , the state implements programs of patriotic education that aim to revive patriotism as an idea of individual spiritual heritage and the basis of social and political stability in the country. The author considers the patriotic mood of the Russian students based on the results of surveys conducted in 2011 and 2016 on the sample of Moscow students. The data present both national and international 'dimensions' of patriotism. The former is constituted by estimates of one's country position in the world, its key problems and contradictions, objects of pride, level of social trust, etc. The international dimension of the patriotic mood is constituted primarily by geopolitical awareness, i.e. the images of neighboring countries.
\end{abstract}

Key words: patriotism, empirical indicators of patriotic mood, national and international 'dimensions', Russian student youth, survey

There are many social concepts that are difficult to be measured in sociological surveys. Moreover, such concepts differ in their practical meaning: some societies emphasize their importance for national self-identification and state building, while others prefer not to use them too often (or at all) in the official discourse or media. One of such concepts is 'patriotism', especially in the post-soviet period [16]. In the 1990s, the previous system of patriotic education collapsed destroying the very concept of patriotism. In the soviet period, this word had clear and unambiguous definitions and positive connotations, while in the early 1990s it acquired negative interpretations with sarcastic overtones due to the concepts 'homeland' and 'state' drift apart after decades of being almost identical. In the 1990s, the series of shock and unsuccessful reforms led to the clear distinction of two concepts that previously were parts of one semantic complex: the 'homeland' 
evoked warm feelings, memories of childhood, of one's home, native land, pride in one's language, culture, history, and people; while the 'state' became a stronghold of bureaucracy that used the word 'patriotism' in manipulations to make people loving their home, native land and the country to feel the same towards the state [6]. This substitution did not work for Russians did not understand why and how their warm feelings for the native land and the people should make them accept military service, protect state interests or pay taxes to the heartless state machine that did not guarantee social security.

However, since the early 2000s, the Russian public opinion polls have shown a gradual increase in the number of respondents who consider themselves patriots. This figure seemed to stabilize in the mid-2000s [10], and by 2010 the number of 'patriots' reached $84 \%$ (Table 1).

Table 1

Would you identify yourself as a patriot?

(closed question, one answer), \%

\begin{tabular}{|l|c|c|c|c|c|c|c|c|c|}
\hline \multicolumn{1}{|c|}{ Year } & $\mathbf{2 0 0 0}$ & $\mathbf{2 0 0 5}$ & $\mathbf{2 0 0 6}$ & $\mathbf{2 0 0 8}$ & $\mathbf{2 0 1 0}$ & $\mathbf{2 0 1 1}$ & $\mathbf{2 0 1 3}$ & $\mathbf{2 0 1 4}$ & $\mathbf{2 0 1 6}$ \\
\hline Yes, certainly & 84 & 47 & 42 & 48 & 41 & 41 & 37 & 48 & 46 \\
\hline Rather yes & & 37 & 42 & 40 & 43 & 39 & 44 & 36 & 34 \\
\hline Rather not & 16 & 8 & 10 & 6 & 9 & 14 & 12 & 9 & 12 \\
\hline Absolutely not & & 2 & 2 & 2 & 1 & 3 & 2 & 3 & 6 \\
\hline Hard to say & 0 & 6 & 5 & 4 & 6 & 3 & 5 & 4 & 2 \\
\hline
\end{tabular}

The 'new Russian patriotism' is a subject of great interest [8] for scientists who study the 'patriotic spirit' of Russians in the comparative perspective to compare the worldview and identification patterns of generations that grew up in differing social-economic, cultural and political contexts, especially in terms of the role of Russia on the geopolitical arena and prospects for its development in the globalizing world. In the majority of such studies, patriotism is defined as respect to the people and the state, the country's history and traditions, i.e. as the fundamental idea of historical and ideological unity that determines the model of national identification and ensures readiness for a patriotic act in the interests of society at the national, group and interpersonal level.

Another social actor seeking to study and enhance the 'new Russian patriotism' is the state that focus on its potential to support the state's national ideology, to revive the legitimacy of the state bodies, and to suppress separatist and nationalist movements. The first five-year state program "Patriotic Education of Citizens of the Russian Federation" aimed to revive patriotism as an idea of individual spiritual heritage and the basis of social and national system ensuring social and political stability [12]. The program focused on the development of patriotic education to enhance citizens' patriotic mood, loyalty to the homeland, readiness to do one's civil and constitutional duties to protect the country through film production, publishing and other creative activities. 
The first state program of patriotic education was followed by the second one that focused on further development of patriotic mood as the basis for national spiritual and moral integrity [13]. The second program took it for granted that the first one had created an institutional system of patriotic education at federal and regional levels and focused on younger generations to improve the evolving system of patriotic education through coordinating councils and local centres. The next program of patriotic education aimed at eliminating extremism and increasing political stability [14]. It claimed that "the system of patriotic education was mainly created", and that "patriotic consciousness of citizens was increasing" (due to regional programs, festivals, exhibitions and competitions devoted to patriotism, etc.), so it was to improve the legislation of the patriotic education, to develop "professional patriotic education" and to encourage people to use the Internet more actively for social and educational purposes.

Let us consider some results of the programs of patriotic education by assessing the general patriotic mood of the Russian students based on the results of the survey conducted in 2011 on the sample of the students of the Peoples' Friendship University of Russia with the questionnaire devoted to patriotic issues. The notion that provoked the warmest feelings in the youth was 'my country' (Russia) (29\%), followed by 'the whole world' (19\%), 'my city/town/village' (17\%), 'my republic, region' $(12 \%)$ and 'Eurasia' (9\%). Almost every second respondent replied to the question 'For you homeland is...' 'Russia as a whole' (46\%), one in four answered 'family and friends' (23\%), 16\% named the city/town/village they were born in, and only $12 \%$ named the region they lived in. The majority (78\%) considered Russia a country with a great potential for future development that should not depend on other countries, especially the United States and the West (62\%). The impressing share of respondents believed that the country's troubles were determined by the inability of its elites to rule and their addiction to selfish interests (62\%), and by the lack of 'normal' laws (70\%), so in the next 10-15 years Russia was believed to turn into a moderately developed country $(58 \%)$.

The majority ( $71 \%$ ) believed that the citizens of Russia had reasons for both pride and negative emotions. Among the answers to the question 'As a citizen of the country I am proud of ...' the undisputed leader of the pride rating was the heroic past of the country (77\%), followed by its art (52\%), sports, cultural, scientific and technological achievements. Every fourth respondent believed that Russians should be proud of the spirituality of one's people. Quite rarely the respondents mentioned the 'economic development of the country', 'Russia's domestic policy', 'power structures', 'protection of the rights and freedoms of the citizens' and the 'social security system' as something they can be proud of (Figure 1). Such a distribution of answers was determined by the perception of the general situation in the country: the majority believed that there was a threat of social unrest (73\%), followed by a threat of mass unemployment (51\%), environmental disaster (53\%), failure of 
the economic policy (58\%), collapse of science and education (53\%), loss of national culture $(50 \%)$, to a greater extent $(66 \%)$ a threat of religious conflicts. Nevertheless, these threats were not considered as leading to the country's disintegration $(78 \%$ rejected such a scenario) or a military dictatorship (83\%).

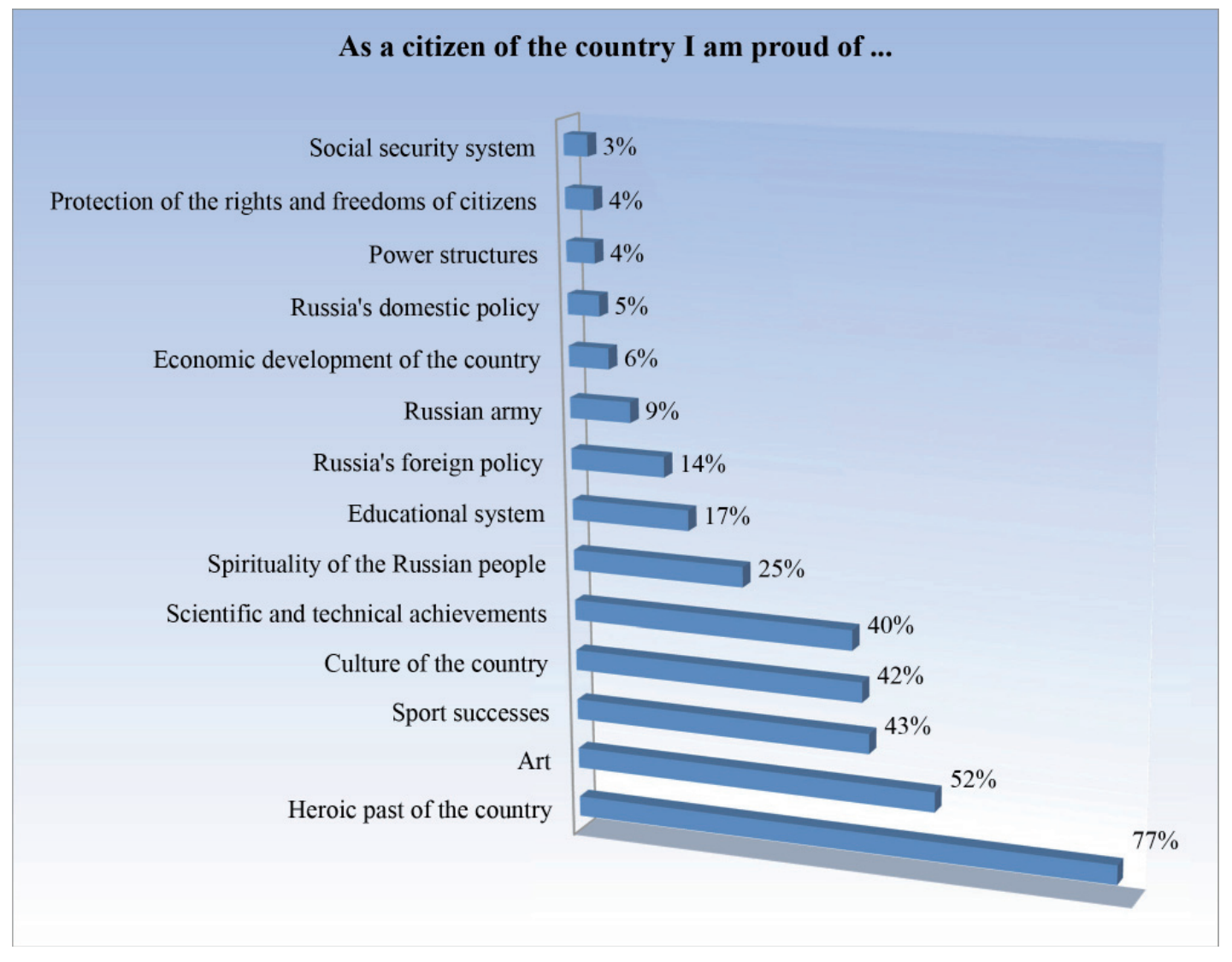

Figure 1

Every fourth respondent (26\%) found it difficult to define oneself in terms of patriotism, $60 \%$ consider themselves patriots, while $14 \%$ do not. Among the hesitating respondents, $37 \%$ reject the unambiguous notion of patriotism, less consider the term too ideological to deal with $(19 \%)$ or out of date $(17 \%)$, others believe that the term is too artificial and intended for manipulations (14\%). However, the majority agreed that patriotism meant love for the country and pride in the achievements of the country and its people, and distinguished the homeland and the state: $65 \%$ believed that the people would take part in military operations rather to protect the country from external aggression than to suppress a coup d'état. Such an interpretation of patriotism (love for the country) is not the one the state seeks to ensure, however, it was confirmed by the public beliefs that the level of patriotism grows under wars, revolutions, radical political upheavals $(74 \%)$, 
and not social conflicts (23\%); an individual patriotism strengthens after the national team's victory at international competitions (59\%), when the Russians (citizens or natives) are awarded prizes for scientific, cultural, sports or other achievements $(42 \%)$, when one goes abroad (39\%) or at the time of national holidays $(38 \%)$. The most patriotic holiday for the Russian students is the Victory Day (85\%).

In general, the Russian youth supported the idea of teaching patriotism (44\%), 27\% believed in its spontaneous development, while the rest insisted that the patriotic mood should be both spontaneous and purposefully set. Half of the respondents mentioned that the Russian government and president only spoke of patriotism instead of taking practical steps to strengthen the patriotic mood.

The current five-year state program of patriotic education claims that in recent years significant efforts have been made to develop the system of patriotic education as uniting government bodies, civil society institutions and families to ensure a strong patriotic mood, a sense of loyalty to native land, and readiness to fulfill civil and constitutional duties to protect the interests of the country [15]. The program mentions the results of the 2013-2014 monitoring of the civilpatriotic and spiritual-moral education to assess the efficiency of patriotic education (youth sports camps, educational clubs named after the heroes of the Soviet Union and Russian Federation, centers for military-patriotic training, presidential sports competitions, cadet schools and Cossack cadet corps, etc.). According to the monitoring data, the share of young Russians taking part in different forms of patriotic education reached $22 \%$ (in more than 22,000 clubs and centers). Thus, the current state program of patriotic education (for 2016-2020) incorporates achievements of previous programs, focuses on ensuring the civil identity and the continuity of the educational process to support the patriotic mood under turbulent social-economic and geopolitical conditions, and aims at all social strata and age groups emphasizing the prior role of patriotic education for children and the youth.

To identify changes (or, on the contrary, the stability) of the patriotic mood of the Russian youth under the programs of patriotic education, let us consider the results of surveys conducted in 2007, 2011 and 2016, when we added a few questions on patriotism in the questionnaire designed to study the Russian students' value orientations. In 2007 and 2011, every second Moscow student (the sample consisted of 1000 respondents representing three educational profiles - technical sciences, humanities and social sciences, and natural sciences) considers oneself a patriot, while every third refused to define his feeling to the country as 'patriotism'. In 2016, the share of respondents naming themselves patriots increased to $58 \%$ due to the decrease of the share of hesitating to provide a clear answer to this question. From 2007 to 2011, the number of young people confidently naming themselves patriots (despite the ambiguity of answers to other questions) remains stable at about half of the sample (Figure 2). 


\section{Do you consider yourself a patriot?}

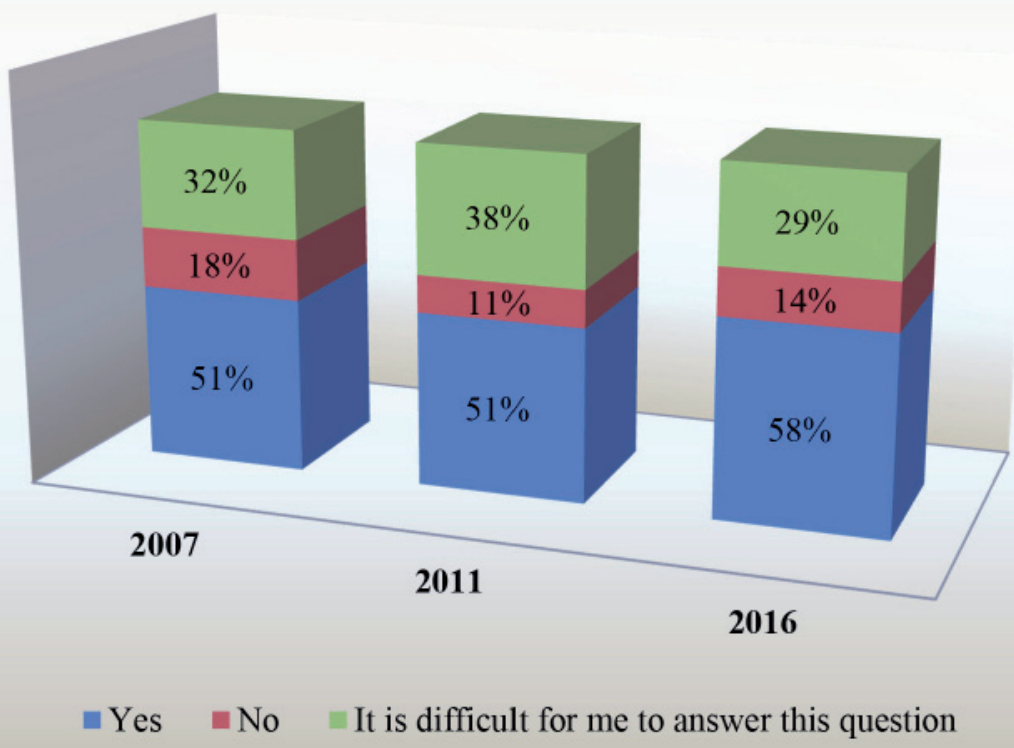

Figure 2

Almost every third student who had difficulties in identifying oneself in terms of patriotism explains one's hesitations by the irrelevance of the word 'patriotism' in the globalizing world (Table 2). The dynamics of answers proves the increasing erosion of the term 'patriot' in the everyday discourse: from 2007 to 2011, it manifested in the increase of the share of those who refused to name their attitude to the country as patriotism; in 2016, this indicator returned to its 2007 level, and the erosion manifested rather in the increase of the share of those who do not understand the meaning of the word.

Table 2

\begin{tabular}{|l|c|c|c|}
\hline $\begin{array}{c}\text { If you did not answer the previous question } \\
\text { ('Do you consider yourself a patriot?'), explain why: }\end{array}$ & $\mathbf{2 0 0 7}$ & $\mathbf{2 0 1 1}$ & $\mathbf{2 0 1 6}$ \\
\hline I do not understand the meaning of the term 'patriotism' & $14 \%$ & $8 \%$ & $18 \%$ \\
\hline $\begin{array}{l}\text { It is difficult for me to clearly define my attitude } \\
\text { to the country as patriotism }\end{array}$ & $51 \%$ & $65 \%$ & $50 \%$ \\
\hline $\begin{array}{l}\text { In the era of globalization, the concept of patriotism } \\
\text { has lost its meaning and is no longer relevant }\end{array}$ & $29 \%$ & $24 \%$ & $26 \%$ \\
\hline Other & $6 \%$ & $3 \%$ & $6 \%$ \\
\hline
\end{tabular}

Regardless of the self-assessment in terms of patriotism, Moscow students are proud of the historical past of the country, its natural resources, cultural heritage, and sports achievements (there was a set of dichotomous scales in the questionnaire) (Table 3). 


\begin{tabular}{|c|c|c|c|}
\hline Year & 2007 & 2011 & 2016 \\
\hline \multicolumn{4}{|c|}{ As a citizen of the country, are you proud of its history? } \\
\hline Yes & $87 \%$ & $89 \%$ & $90 \%$ \\
\hline No & $13 \%$ & $11 \%$ & $10 \%$ \\
\hline \multicolumn{4}{|c|}{ As a citizen of the country, are you proud of its natural resources? } \\
\hline Yes & $87 \%$ & $88 \%$ & $86 \%$ \\
\hline No & $13 \%$ & $12 \%$ & $14 \%$ \\
\hline \multicolumn{4}{|c|}{ As a citizen of the country, are you proud of its cultural heritage? } \\
\hline Yes & $91 \%$ & $87 \%$ & $85 \%$ \\
\hline No & $9 \%$ & $13 \%$ & $15 \%$ \\
\hline \multicolumn{4}{|c|}{ As a citizen of the country, are you proud of its sports achievements? } \\
\hline Yes & $78 \%$ & $73 \%$ & $77 \%$ \\
\hline No & $22 \%$ & $27 \%$ & $23 \%$ \\
\hline
\end{tabular}

Until 2011, the position of Russia in the international arena was a source of pride for every fourth student, and the Russian army - for every fifth. In 2016, these data changed, probably due to the active foreign policy of Russia that includes military campaigns, food anti-sanctions and embargo, and other 'presentational' steps that affect public sentiments. Thus, in 2016, the position of Russia in the international arena and the army became a source of pride for $56 \%$ and reached the level of scientific achievements and educational system. Other objects of pride and anti-pride stayed the same: though there are fluctuations in figures there is still a clear trend proving that the pride in cultural heritage (achievements of previous generations) has remained at the highest level since the mid-2000's, while the dissatisfaction with today's life in Russia is strikingly high. In 2007 and 2011, the common areas of students' dissatisfaction (anti-pride figures are about $90 \%)$ were development of economic and social spheres (13\% found grounds for pride here), the rights and freedoms of individuals (17\%), activities of state bodies $(15 \%)$, and the standards of living of the population (10\%). In 2016, the level of discontent partially decreased but the areas of public discontent remained the same: development of economic and social spheres (36\% find grounds for pride here), the rights and freedoms of individuals (45\%), activities of state bodies (42\%), and the standards of living of the population (34\%).

Such a high social discontent is closely related to the level of social trust. In 2011, only one-third of students trusted the government, Russian and international NGOs, courts and media; every fourth - the Federation Council and Public Chamber; one in five - the State Duma (68\% rather did not trust). An absolute leader of the students' trust rating was the president (58\%) followed by the church $(50 \%)$, banks (47\%) and big business (40\%). The 'anti-leaders' of the social trust rating were political parties ( $72 \%$ of the respondents did not trust them), police and law enforcement agencies (77\%), and the army (65\%). In 2016, the situation changed 
significantly though the most trusted is still the president (63\%) (Figure 3). There are three groups of social institutions according to the level of youth's trust: (1) almost every second respondent trusts the Federation Council, church, courts and government; (2) from $40 \%$ to $46 \%$ trust the State Duma, Public Chamber, police and law enforcement agencies, army, local NGOs, big business, and banks; (3) every third respondent trusts the mass media, international NGOs and political parties. Thus, there is an increase of social trust to the basic social institution compared to 2011 (government, Federation Council, courts, State Duma and police), while the outsiders of the trust rating stay the same (the third group with the lowest level of trust), i.e. the 'national measurement' of the patriotic mood of the student youth seem to strengthen.

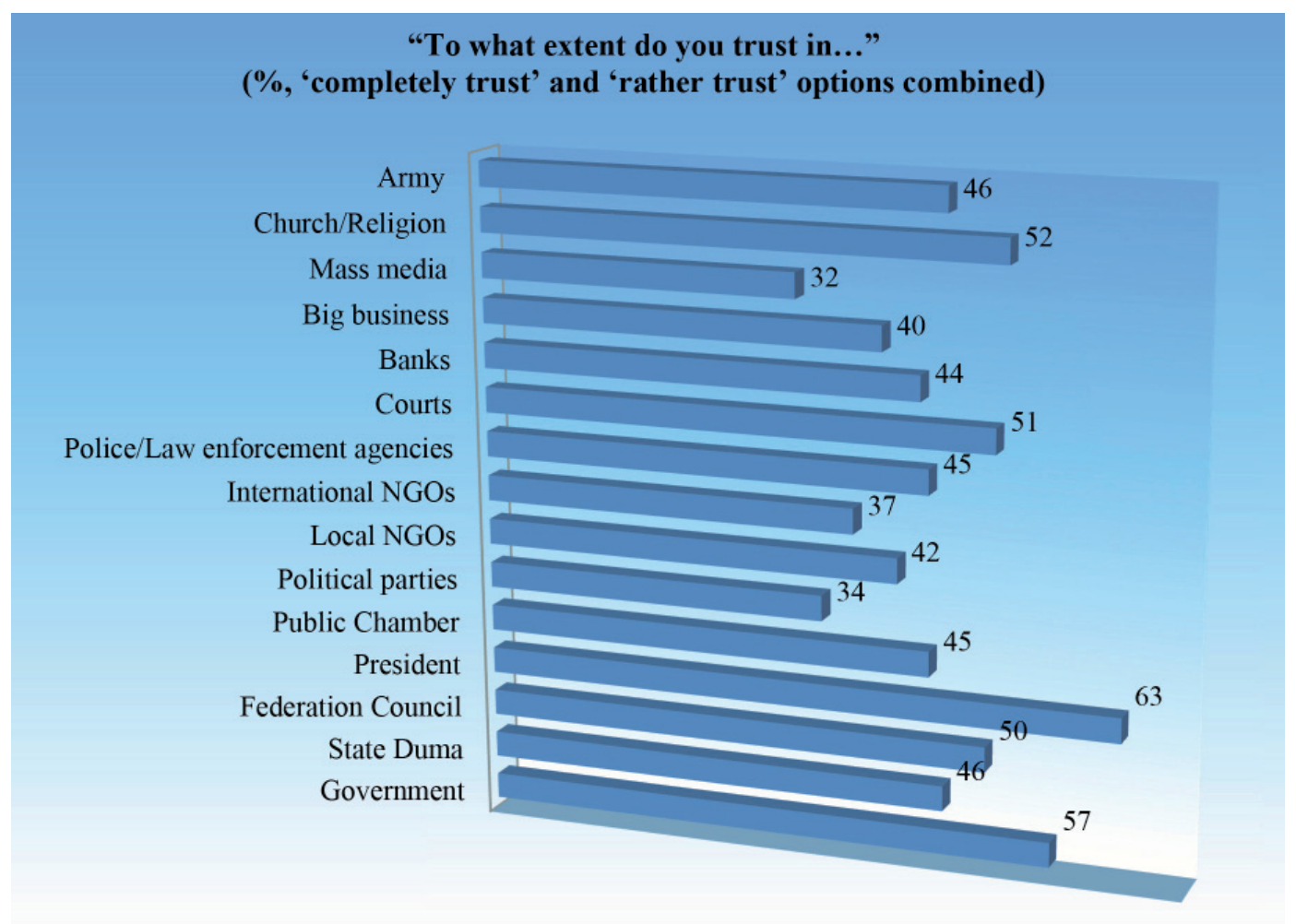

Figure 3

However, the strengthening social trust does not make students ignore the problems of the society. Compared to 2011, the most acute problems of the Russian youth did not change significantly if we consider leaders and outsiders of the list, though there are changes pointing to a more positive perception of one's generation (Table 4). The most acute problems of the youth are still drug and alcohol addiction, followed by moral degradation, but not the crime (though the emphasis is still on the behavioural features, the crime is no longer among the leaders of the list). Then comes the group of 'objective' factors determining the above-mentioned 
problems: unemployment, lack of financial resources, corruption, no access to education, and general economic, civil and legal situation. In 2016, the students became more concerned with the limited opportunities for leisure (boring life), lack of mutual understanding with parents, and political situation in the country and abroad, which were at the end of the list five years ago.

Table 4

\begin{tabular}{|c|c|c|}
\hline $\begin{array}{c}\text { In your opinion, what are the most acute } \\
\text { problems of today's Russian youth? }\end{array}$ & $\mathbf{2 0 1 1}$ & $\mathbf{2 0 1 6}$ \\
\hline Drug addiction & $\mathbf{7 6 \%}$ & $\mathbf{5 6 \%}$ \\
\hline Alcohol addiction & $60 \%$ & $55 \%$ \\
\hline Moral degradation of society & $48 \%$ & $46 \%$ \\
\hline Smoking & $38 \%$ & $44 \%$ \\
\hline Crime & $\mathbf{3 1 \%}$ & $\mathbf{1 8 \%}$ \\
\hline Health problems & $28 \%$ & $30 \%$ \\
\hline Unemployment & $25 \%$ & $28 \%$ \\
\hline Lack of financial resources & $25 \%$ & $21 \%$ \\
\hline Lack of support from the state & $24 \%$ & $17 \%$ \\
\hline Corruption & $19 \%$ & $17 \%$ \\
\hline Inaccessibility of education & $16 \%$ & $17 \%$ \\
\hline Economic situation in the country & $14 \%$ & $15 \%$ \\
\hline Violation of civil rights and liberties & $13 \%$ & $11 \%$ \\
\hline Limited opportunities for leisure, boring life & $\mathbf{1 2 \%}$ & $\mathbf{2 1 \%}$ \\
\hline Lack of mutual understanding with parents & $\mathbf{1 2 \%}$ & $\mathbf{1 8 \%}$ \\
\hline Political situation in the country and in the world & $\mathbf{4 \%}$ & $\mathbf{1 0 \%}$ \\
\hline
\end{tabular}

The above indicated changes in the answers can be explained by differences of national and international dimensions of the patriotic mood: one thing is to speak about one's country as it was in the early 2010s, the other thing is to speak about one's country today for it seems to regain its former positions in the international arena (despite the unsolved domestic problems), which is also proved by twice more concerned with the political situation in 2016 compared to 2011 (10\% vs. 4\%). However, these concerns did not change the youth's perception of the Russian foreign policy. In both 2011 and 2016, every second respondent hesitated to evaluate the consequences of Russia's rapprochement with the West as positive or negative (preferring to say there are both useful and harmful results), while the number of estimating this rapprochement as rather positive (33\%) still exceeds the share of evaluating it as rather negative (17\%).

The international dimension of patriotic mood is constituted by geopolitical awareness, i.e. the images of neighboring countries. Since the early 2000 s, the Russian public opinion concerns in the foreign policy have strengthened, though there is no country or a group of countries considered a threat by at least a half of 
respondents. Russians usually name the United States and China first in the list of threats to the country: the former due to the aggravation of Russian-American relations; the latter due to the relatively sudden appearance of a new superpower on the eastern borders of Russia that (presumably) claims on the Far East [1]. In the early 2000s, the Public Opinion Foundation started a 'Geoproject' as a series of surveys about the Russians' perception of about 40 countries [3]. Already in 2000-2001, these surveys proved that the Russian public opinion is monolithic and focuses on geopolitical features when considers the leading world powers (China is believed to be a giant country with a growing role in world politics and economics), while the images of small countries with insignificant geopolitical role are very diverse (the image of Greece is a bizarre mixture of historical, mythical and touristic facts). Since the early 2000s, Russians do not seem to experience "a paranoid fear of the outside world often attributed to them. The majority of Russians... either claim that the country has nothing to fear, or hesitate to say whether it has dangerous enemies. Russians have little interest in the outside world and find new threats and hopes inside the country" [11]. Moreover, there are too many countries everybody knows, and the geopolitical awareness is both stereotyped and depending on the current official and media discourses. Thus, in 2015, 68\% of Russians declared the bad attitude to the United States (32\% - to the Americans), 60\% - to the European Union, $56 \%$ - to the Ukraine (25\% - to the Ukrainians), but not to Georgia (32\%) or China (14\%), certainly, due to the lack of ongoing political or military conflicts with the latter two [4].

Our surveys on value orientations of the Moscow student youth in 2011-2013 were supplemented by a thematic block to reveal the images of neighboring countries $[5 ; 17]$. We studied the image of China in 2011, the image of Serbia and Kazakhstan in 2012 and 2013 respectively. In particular, we asked respondents to choose from the list of countries those they thought most positively about. The results showed that there were no positive 'heroes': almost every third respondent thought most positively about England and France, every fourth about Spain, Japan, Germany (its position fluctuated between every third and forth respondent), Belorussia and Switzerland, every fifth - about the United States, China and Cuba.

In 2016, we used one questionnaire to identify the persistent stereotyped images of neighboring countries in the student youth outlook (on the same sample of 1000 Moscow students representing three educational profiles) [7]. The data allow to identify three groups of countries according to their perception by the student youth: most positively perceived - Belorussia (almost every second respondent); positively perceived by about a third - China (probably believed to be the most important Russian geopolitical partner), Italy and Spain (perfect places to travel and spend vacations), and Cuba; every forth chose Serbia, Japan, England, France and Germany; every fifth - Ukraine, Switzerland, USA and the Czech Republic; every tenth - Australia (probably due to the geographical remoteness and geopolitical imperceptibility), South and North Koreas, and Egypt. Compared to 2011, the USA 
remains at the end of the list of positively perceived countries, Belorussia significantly improved its position together with China and Cuba, while some European countries (England and France) lost some points in the rating (probably due to the anti-sanctions and anti-NATO rhetoric of the Russian political leadership).

Certainly, we admit the limitations of such a comparison, but without comparative analysis, one cannot claim the persistent character of stereotypes. There is a long tradition of comparative studies in sociology, which proves that opinion polls are applicable for testing hypotheses [2] (such as the persistent character of the stereotyped images of neighboring countries) and 'harmless' as being 'ascertaining rather than evaluative' [9. P. 10], especially in different time points. Therefore, in the Soviet period, the concept of patriotism had a coherent supra-ethnic interpretation and positive associative array; in the 1990s, it acquired negative connotations for the previously identical concepts 'homeland' and 'state' got separated in the public opinion: the former caused warm emotions, the latter came in a strong 'coupling' with the bureaucratic system manipulating the concept 'patriotism' to make the populations perceive the state as a homeland despite the crisis social and economic situation, lack of social guarantees and worsening live standards. Today we witness the strengthening of the patriotic mood due to various reasons, but mainly to the state programs of patriotic education, better social and economic situation compared to the 'dark 1990s', and the revival of the discourse about Russia as a powerful geopolitical figure that should stand strong and in solidarity against internal and external threats.

(C) Trotsuk I.V., 2018

\section{REFERENCES}

[1] Fears of Russians and threats to the country. 2013. URL: http://wciom.ru/index. php?id=236\&uid=113634 (In Russ.)

[2] Khizrieva A.G., de Munck V.C., Bondarenk, D.M. The Moscow School of quantitative cross-cultural research. Cross-Cultural Research. 2003. Vol. 37. No. 5.

[3] Kolosov V. 'Low' and 'high' geopolitics. 2002. URL: http://bd.fom.ru/report/map/ oz02061904 (In Russ.)

[4] Monitoring of the Russians' attitudes to other countries. 2015. URL: http://www.levada. ru/2015/01/01/monitoring-otnosheniya-rossiyan-k-drugim-stranam-sentyabr (In Russ.)

[5] Narbut N.P., Trotsuk I.V. Sociological evaluation of neighboring countries' images as perceived by Russian students: Methodological and content components. RUDN Journal of Sociology. 2012. No. 4. (In Russ.)

[6] Narbut N.P., Trotsuk I.V. The Russian youth outlook: Patriotic and geopolitical components. Sociological Science and Social Practice. 2014. No. 4. (In Russ.)

[7] Narbut N.P., Trotsuk I.V. Neighboring countries' images: Persistent stereotypes of the Russian student youth. RUDN Journal of Sociology. 2017. Vol. 17. No. 3. 
[8] New Russian patriotism: national, statist, or civil. 2014. URL: http://wciom.ru/index. php?id=268\&uid=13603 (In Russ.)

[9] Noelle-Nuemann E. The Spiral of Silence: Public Opinion. Moscow: Progress-Academija; 1996. (In Russ.)

[10] Patriotism in Russia; if tomorrow is war, if tomorrow is a military campaign. 2016. URL: https://wciom.ru/index.php?id=236\&uid=115747 (In Russ.)

[11] Phantom threats: Russians are not prone to the paranoid fear of the outside world. 2011. URL: http://fom.ru/Mir/10097 (In Russ.)

[12] State Program "Patriotic Education for Citizens of the Russian Federation for 2001-2005”. 2001. URL: http://base.garant.ru/1584972 (In Russ.)

[13] State Program "Patriotic Education for Citizens of the Russian Federation for 2006-2010”. 2005. URL: http://base.garant.ru/188373/\#100 (In Russ.)

[14] State Program "Patriotic Education for Citizens of the Russian Federation for 2011-2015”. 2011. URL: http://base.garant.ru/199483 (In Russ.)

[15] State Program "Patriotic Education for Citizens of the Russian Federation for 2016-2020”. 2015. URL: http://static.government.ru/media/files/8qqYUwwzHUxzVk H1jsKAErrx2 dE4q0ws.pdf (In Russ.).

[16] Trotsuk I., Šuvakoviç U. The value of patriotism for students in Russia and Serbia. Serbian Political Thought. 2013. Vol. 7. No. 1.

[17] Trotsuk I.V. The image of Serbia in the Russian society: The results of the survey of Moscow students. RUDN Journal of Sociology. 2012. No. 3. (In Russ.)

\title{
Патриотизм как ценность в глобализирующемся мире: национальное и международное «измерения»
}

\section{И.В. Троцук}

\author{
Российский университет дружбы народов \\ ул. Миклухо-Маклая, 6, Москва, Россия, 117198
}

В статье патриотизм выступает как одно из наиболее сложных для социологического «измерения» понятий, поскольку у него есть разные интерпретации и индикаторы, имеющие скорее дискурсивную природу, чем объективно детерминированные. Автор приводит результаты общероссийских опросов общественного мнения 2010-х, 2000-х и 1990-х годов, чтобы показать различия в трактовке патриотизма в разные десятилетия через изменение доли респондентов, которые соглашались идентифицировать себя как патриотов. Данный показатель стабилизировался в середине 2000-х годов, в значительной степени благодаря попыткам государства использовать идею патриотизма для легитимации государственных органов управления и формирования российской гражданской солидарности в условиях нарастания темпов глобализации. С 2001 года государство последовательно реализует программы патриотического воспитания, призванные возродить патриотизм как идею личностного духовного наследия и фундамент социальной и политической стабильности общества. Автор рассматривает патриотический настрой российских студентов на основе результатов социологических опросов, проведенных в 2011 и 2016 годы на выборке московского студенчества. Полученные данные позволяют 
оценить как национальное, так и международное «измерение» патриотизма. Первое измерение конституируется оценками положения страны на международной арене, ее основных проблем и противоречий, объектов национальной гордости, уровня социального доверия и т.д. Международное измерение формируется преимущественно геополитическими опасениями и ожиданиями, поэтому его можно оценить через реконструкцию образов стран-соседей страны.

Ключевые слова: патриотизм, эмпирические индикаторы патриотического настроя, национальное и международное «измерения», российская студенческая молодежь, опрос

\section{Об авторе:}

Троцук Ирина Владимировна - доктор социологических наук, доцент кафедры социологии факультета гуманитарных и социальных наук РУДН. (e-mail: trotsuk_iv@, rudn.university). 